\title{
Cash Waqf Fundraising at Indonesian Waqf Agency (BWI)
}

\author{
Fauziah $^{1}$, Umul Hidayati ${ }^{2}$ \\ \{fauziahmz2606@gmail.com¹, hidayatikuncoro@yahoo.com² \\ Research and Development Centers, Religious Community Guidance and Religious Services ${ }^{1}$, Research \\ and Development Agencies, and Training Education, the Ministry of Religion ${ }^{2}$
}

\begin{abstract}
In the light of islamic financial literacy, the study aims to analyze the application of cash waqf and its supporting or inhibiting factors within the management of Indonesian waqf agency (BWI). Researchers designed a qualitative descriptive approach to contribute to the agency of knowledge of economics and social sciences. This research proves that the Indonesian waqf agency has the all opportunities to develop more for the cash faqf potential, within the fact tendency of increasing receipt for cash waqf along the periods. The supporting factor for this potential is the existence of 22 Islamic banks that appointed as 'deposit beneficiary for Cash Waqf' experienced in managing the application of cash waqf and supported with a range of work office available throughout Indonesia. The inhibiting factor for this potential is the lack of literacy socialization of the cash waqf instrument to the public. Many people do not know that waqf might be in the form of financial assets, and not just applicable for fixed assets only.
\end{abstract}

Keywords: fundraising, cash-wakaf, BWI.

\section{Introduction}

Waqfis a maliyah observance that serves for the benefit of the society in order to show devotion to Allah SWT, and the rewards will continue flowing as long as the waqf property is utilized properly. Waqfis a manifestation of one's piety regardless the material profit that one will gain. Waqf has been practiced in the life of Muslims since the years of Prophet Muhammad SAW.

Waqfis a potential that hasn't been fully utilized and developed.The potential of waqf,especially money waqf can be used as a fund alternative to settle many economic and social problems towards the financial independency that ends in the benefit of the people.The recent development of money waqf is expected to contribute more on people's social and economic life. If20 million of the Muslim population are willing to donate the waqffor Rp. 1,000/day or Rp. 30,000 /month, so the amount of the money waqf collected is 7.2 trillion per year. If the collected fund increased every year, the amount of the money waqf wouldcumulatively suffice as a capital for social and economic life that can help reduce the poverty. 
These two important issues in the Indonesian economy can actually be solved by using Islamic economic instruments, namely zakat and waqf. Based on the data as of March 18, 2016 it turns out that Indonesian waqf have tremendous potential. The surface area of land waqf in Indonesia is 4,359,443,170 square meter, consists of 435,768 locations with details of 287,160 certified locations and 148,608 non-certified locations. Based on Bank Indonesia's identification of waqf potential in Indonesia of 3.7 billion square meter with an economic potential of 370 trillion. If the potential of waqf is managed properly, it can improve the living standard of Indonesian people. So far, waqf empowerment in Indonesia tends to be limited only for worship, education, and funeral activities and less leads to productive waqf and money waqf.

Money waqf has a very important meaning for the economy of the country, as a means of transfer of wealth from the rich to entrepreneurs and citizens in financing various religious, social, and educational programs in Islamic countries. In addition, money waqf can also serve as a strategic investment to eliminate poverty and deal with backwardness in the areas of economics, health, and research. Money waqf in some Islamic countries also replaces most income taxes for funding social projects.

The popularity of money waqf came after Professor Mannan socialized it in Bangladesh through Social Investment Bank Limited (SIBL). SIBL created a Money WaqfCertificate to raise funds from rich people and share the earned wages of the money waqf it has collected for the poor. The popularity of "money waqf" was caused by the flexibility of spreading the benefits of the money to the mustadh'afin (poor people and the oppressed) and dhu'afa (poor people) in all places. Today, many Islamic governments are deliberately establishing the Waqf Ministry and regional waqf institutions. Recent studies on waqf have begun to rely on an institution, which in it provides facilities for managers'management to improve efficiency. Various proposals are made as a requirement for the progress and development of money waqfis with the development of Islamic Waqf Bank. However, the establishment of the bank depends on the policy of the money waqf.

Waqf fund for Muslims in Indonesia is relatively new, this can be seen from the regulations underlying it. The Indonesian Council of Ulama (MUI) has just issued a fatwa on May 11, 2002 which allows the payment of money with the condition that the basic value of waqf must be guaranteed to be sustainable. While the Law Number 41 Year 2004 regarding Waqf was only promulgated on 27 October 2004, and Government Regulation Number 42 Year 2006 regarding its implementation was enacted on December 15, 2006.

The waqf practice in Indonesia faces many problems especially for waqf fund, i.e. management problems, unprofessional nadzir, ineffective socialization, redundant unproductive waqf, and the perception of the society that waqf should be in form of immovable objects such as land or building. Therefore, it is necessary to socialize and manage the fundraising strategy in waqf fund, introduce the waqf fund to the society and manage the waqf fund in the proper and modern way.

\section{Research Questions}

1. How is the potential of cash waqf at Indonesian Waqf Agency (Badan Wakaf Indonesia/BWI)?

2. How is the growth of cash waqf at BWI?

3. What are the supporting factors and the deterring factors in cash waqf practices at BWI? 


\section{Methodology}

The type of this research is a qualitative research supported by economic and social approaches. There are two sources of data processed in this research, namely:

a. Primary Data Source: collected through interviews with practitioners, ulamas, academicians, and regulators who have a good understanding about the problem being discussed.

b. Secondary Data Source: collected through indirect sources, such as documents, people, etc. Secondary data is used to complete the primary data as well as to support the results of this research

\section{Discussion}

\subsection{Indonesia Waqf Board (BWI)}

IndonesiaWaqfBoard is an institution authorized by Indonesia government as a waqf administrator in Indonesia. The position of Indonesia Waqf Board, according to Waqf Regulations Number 41 year 2004 article 48, it is determined that Indonesia Waqf Board is an institution serves as a media to develop and bring the nasional waqf forward. ${ }^{1}$ Besides, in waqf regulations also set that Indonesia Waqf Board is an independent institution in running its tasks. ${ }^{2}$ IndonesiaWaqfBoardlocated in Jakarta and has the authority to establish its representatives in other provinces and/or districts/cities depends on its necessities. ${ }^{3}$ In regulation explanation, it has been set that the Indonesia Waqf Board's representative establishment in some districts can be done after the BWI consult with the local government. ${ }^{4}$

\section{Cash Waqf Fundraising}

Fundraising can be interpreted as an activity to collect funds and other sources (as waqif/donors $)^{5}$. The definition of fundraising according to various sources are as follows: "Fundraising is the process of soliciting and gathering money or other gifts in-kind, by requesting donations from individuals, businesses, charitable foundations, or governmental agencies. Although fundraising typically refers to efforts to gather funds for non-profit organizations, it is sometimes used to refer to the identification and solicitation of investors or other sources of capital for-profit enterprises." 6

The Ministry of Religion defines Fundraising as an activity to raise some funds of individuals, organizations, or legal entities ${ }^{7}$. Fundraising can also be said to be a process to influence people to do the charity in the form of giving money as waqf as well as for donation of

\footnotetext{
${ }^{1}$ Undang-undang Nomor 41 Tahun 2004 tentang waqf, pasal 47, ayat (1).

${ }^{2}$ Undang-undang Nomor 41 Tahun 2004, pasal 47, ayat (2)

${ }^{3}$ Undang-undang Nomor 41 Tahun 2004, pasal 48.

${ }^{4}$ Penjelasan dalam Undang-undang Nomor 41 Tahun 2004, pasal 48.

${ }^{5}$ Kim Klein, Fundraising for Social Change, Fourth Edition, (Oakland California: Chardon Press, 2001).13

${ }^{6}$ Suparman, "Strategi Fundraisng Wakaf Uang: Jurnal Wakaf dan Ekonomi Islam", Vol.II, No 2, April 2009.6

${ }^{7}$ Republika, manajemen fundraising dalam penghimpunan harta wakaf, 16 Desember 2008.
} 
waqf property management. The meaning of "to influence" here is to: notify, remind, encourage, persuade, seduce, or lure. Fundraising is closely related to the success of a person, organization, or legal entity to invite and influence others to generate awareness, concern, and motivation to do the waqf. Fundraising is the process of influencing the community to do the waqf which in its implementation includes the following elements: Needs Analysis, Segmentation, Waqif's Profile Identification, Products, Transaction Fee Prices, and Promotion ${ }^{8}$.

\section{Money Waqf Issues in BWI}

The issues on money waqf is pretty complex. In general, the issues that are often found are the issues related to the society's understanding about the waqf regulations.Looking back at the waqf history in Indonesia that is always about an unproductive land has set the society's mindset that only lands that can be donated as waqf to be utilized as a cemetery or worship activities, like graveyards and mosques. This is in line with Nadratuzzaman Nosen's argument that explains that majority of Indonesia's societies understand waqf traditionally, it means that waqf is only limited to a worship infrastructure and graveyard. ${ }^{9}$ There are even some people feel sinful when the waqf land is used for productive activities like shophouses, minimarkets, and other activities because they don't see the worship values in those activities.Hence, the existing waqf is only focused on fulfilling the needs for worship activities and very little of the waqf that is directed to increase the people's economic power.Until now, the productive waqf in Indonesia are not fully developed.Very little people that are willing to develop the productive waqf let alone doing the money waqf.And if you look at the purpose of the waqf, it is not only to achieve goodness in hereafter, but also to achieve goodness in the world by realizing the even prosperity on all levels of society. This is in accordance with the theory of benefits in Islamic law.

The money waqf emerge along with the current development, despite the controversy about the term among some of madhhab ulama, but by looking at its benefits the waqf system is very potential to increase the community's wealth and cultivate the people's economy, then this money waqf will be accepted by the community.Therefore, the community's mind-sets or understanding about waqf needs to be enlightened.If we look at the history of waqf, both done by Prophet Muhammad SAW and his companions in addition to mosques and educational areas, there were many waqf in the form of gardens where the results of the crops are shared for those in needs, because basically the purpose of the waqf stipulation in sharia law or shadaqah jaariyahwas to make us help each other.That's why it is necessary to raise the awareness from the community to be willing to lend a hand, especially those who blessed with more wealth by Allah SWT, to help their own kind who are in needs because Islam teaches us to help each other.

The issue on money waqf according to Uswatun Hasanah and Ahmad Djunaidiis the low awareness in society to do the money waqf. This was mainly caused by the lack of socialization about money waqf, so that until now money waqf is not widely known in Indonesia societies and has not developed well enough. ${ }^{10}$ According to Ahmad Djunaedi, BWI has socialized about the

\footnotetext{
${ }^{8}$ Suparman, "Startegi Fundraisng Waqf Uang: Jurnal Waqf dan Ekonomi Islam, Vol.II, No 2, April 2009.11 ${ }^{9}$ Wawancara dengan Nadratuzzaman Nosen, Pengurus Dewan Syariah Nasional (DSN), di kantor pusat DSN pada tanggal 18 Januari 2017.

${ }^{10}$ Wawancara dengan Ahmad Djunaedi di BWI pada tanggal 20 Desember 2016 dan Uswatun Hasanah di fakultus Hukum Universitas Indonesia pada tanggal 12 januari 2017
} 
money waqf, but he admitted that it has not been optimal due to the budget constraints. ${ }^{11}$ The interview with some members of Majelis Taklim and some postgraduate friends in UIN Syarif Hidayatullah Jakarta, disclosed: "We never heard about the money waqf and we still don't know that we can do the money waqf, and they don't know about the minimum amount, how to do it and for what benefits. Though we prefer to do the charity with money rather than goods because it is more practical." ${ }^{12}$ While some of them have already heard about the money waqf, but they still don't know how to do it. ${ }^{13}$

This phenomenon proves that, in general, not many people really know and understand about the money waqf, even the academicians. There is a saying, you can't love what you don't know. Knowing about the money waqf is very important, because by knowing how to do the money waqf, the benefits of it, where to do it, what else that can be donated as waqf, for whom and to whom the money waqf is channelled, and who can be the nadzir, the people will be motivated and can do the money waqf in the right way.

Experts agreed that the main issue in developing the money waqf fundraising in Indonesia is socialization. The lack of operational cost is a very crucial issue faced by most of waqf administrators today.According to almost all experts, the operational cost is the most urgent issue that will determine the implementation of money waqf socialization.

According to Uswatun, to increase the screening of money waqf fund, the first step needs to be taken is by increasing the promotion. The most important issue of socialization is promotion issue. Many preceding researches about the role of marketing on an organization, one of it was done by Bund and Carrol that stated that there are a role and function change in the promotion of an organization. ${ }^{14}$ Marketing is getting more accepted as a cornerstone from an organization's plans and hold a critical role in an organization's management. Howard suggested a new theory from an organization that tries to set the role of marketing and other functional areas in formulating goals and strategic planning process.

Research keep developing in look into the marketing function in an organization, such as a research taken by Webster which stated that there are needs of new paradigm from a marketing function in an organization i.e. not only selling but also responsible to understand the customers and developing as well as providing values to the customers. ${ }^{15}$ Workman, Homburg, and Gruner also doing research on the role of marketing that vary according to its business context.At the end of the discussion, the researcher proposed a work frame that will integrate the organization's marketing that has been previously researched. Homburg, Workman, and Krohmer stated their research result that found that the marketing still holds the substantial influence.

The government budget is also the most supporting factor to optimize the waqf in Indonesia.According to some experts, the waqf budget is now on the lowest position compared to other budgets. ${ }^{16}$ Considering the nadzir coaching and training activities and land waqf certification,

11 Wawancara dengan Ahmad Djunaedi di BWI pada tanggal 20 Desember 2016

${ }^{12}$ Wawancara dengan Majelis Taklim masjid Al Mujahidin pada tanggal 1 Agustus 2017

13 Wawancara dengan mahasiswa Pascasarjana UIN Syarif Hidayatullah Jakarta pada tanggal20 April 2017

${ }^{14}$ H. Bund and J.W. Carrol, “ The Changing Role of The Marketing Function”, Journal of Marketing, 21, No 2 (2005), 270-286

15 Jr. F.E. Webster, “ The Changing Role of Marketing in The Corporation”, Journal of Marketing, 56 No ,4 (2012), 1-17

${ }^{16}$ Interview with Ahmad Djunaedi at BWI onDecember 20, 2016 
it is an authority for the government and BWI that needs a big amount of budget.This promotion is very important to make the people willing to do the waqf money especially by LKS-PWU assigned by the Minister of Religious Affairs. But, in fact, based on the writer's experiences, there are many LKS-PWU officials who doesn't aware about the money waqf in their organization.Indeed, without adequate knowledge on money waqf, they will not able to promote the money waqf to the customers/society. Looking at this fact, according to Ahmad Junaidi, LKSPWU still thinks that money waqf is not as profitable for them.Right now there are 22 LKS-PWU that are officially recorded on the Indonesia Ministry of Religious Affairs.Unfortunately, not all LKS-PWU able to optimizing the money waqf socialization to the society and its customers, so there are not many people aware that there are a Sharia Financial Institution assign by the Ministry of Religion.

3.Money Waqf Fundraising Practice in Indonesia Waqf Board (BWI)

The Law number 41 year 2004 about Waqf Article 28 regulates the acceptance on money waqf can be done through the Sharia Financial Institution-Money Waqf Administrator (LKSPWU) assigned by the Minister of Religious Affairs. The definition of LKS as stated in Article 1 Paragraph (9) in Government Regulation Number 42 Year 2006 is an Indonesian legal entity engaged in the field of Islamic finance. They said thatLKS must meet the requirements as referred to in Government Regulation Number 42 Year 2006 Article 24 paragraph (3), namely: LKS assigned by the Minister of Religious Affairs as LKS-PWU, submits a proposal and obtains recommendation from its supervisory authority, is a legal entity and has an article of association, operational offices in regions of Republic of Indonesia, engaged in Islamic finance, and serves to receive a deposit (wadiah). In this case, the sharia banking namely BUS, UUS, and BPRS can generally meet the requirements.

The role of LKS-PWU is very strategic particularly in developing the money waqf in Indonesia. One of these strategic roles related to the legal status of this institution since it was directly assigned by the Minister of Religious Affairs as an authorized institution that serves to receive the money waqf.This is mentioned in the Law No. 41 year 2004 Article 28 about Waqf that stated: "The waqif may donate the movable objects in the form of money through a sharia financial institution assigned by the minister." In this connection, the minister has the authority to assign the particular sharia financial institution that meets the requirements on the advice and consideration from Indonesia Waqf Board (Article 24 paragraph 1 Explanations). Not all LKS can be the Muslims' money waqf receiver.The Law No. 41 Year 2004 set certain requirements for LKS to be able to receive the money waqf from the people. Those requirements include:

1) LKS needs to submit a written proposal to the Minister of Religious Affairs.

2) Attaches the articles of association as a legal entity.

3) Owns operational offices in the region of Republic of Indonesia.

4) Engages in the field of Islamic finance.

5) Serves to receive a deposit (wadiah).

These strict requirements are intended to ensure the money waqf collected in these sharia financial institutions can be guaranteed for its sustainability and security (Law 41/2004). LKS's strategic role in developing the money waqf in Indonesia specifically related to its networking.Most Sharia Financial Institutions have branch offices and numerous ATM facilities, 
SMS banking, Internet banking, and auto-debit facilities. The widespread network and bank facilities will in turn facilitate the Muslims in Indonesia to participate in doing the money waqf.In addition to the widespread network, LKSs in Indonesia also has a reliable Human Resources in management that can support the efforts in achieving the people's money waqf funds optimally.In addition, the funds collected in these LKSs are generally under the guarantee of the Deposit Insurance Agency (LPS)so that the funds collected can be very secured (Siregar 2011). This strategic role fosters new optimism about how LKS-PWU can support the productive money waqf movement in Indonesia.Practically, LKS-PWU holds the strategic role in managing and developing the waqf properties as mandated by the waqif to the nadzir.The management and development of money waqf can only be done through the investment on LKS's products or sharia financial instruments. The said investment is meant that the funds trunsted to LKS-PWU have to be invested based on sharia contracts such as mudharabah or other contracts that are not contrary to the sharia law.

The involvement of LKS-PWU in raising the money waqf funds because in general LKS optimizes the money waqf fundraising and management, such as: (1) has a network of branch offices spread across provinces, districts, or cities in Indonesia.The strong management with relatively wide network of banking offices are expected to be more effective in socializing the money waqf to the community, so that the waqf fundraising would be more optimized and helps the effectivity and efficiency of the waqf funds delivery to mauquf 'alaih, (2) the ability as a fund manager, banking institutions are institutions with experiences in managing people's funds and also well experienced as an intermediary institution of surplus spending unitwith deficit spending unit, and with those experiences, if the sharia banking is trusted to manage the money waqf, it can be quickly implemented because of their experiences. This cannot be separated from the professional human resources in LKS-PWU. (3) Experiences, information network, and distribution map. As a fund administrator to be distributed to particular parties, the banking institution has the experience, information, and distribution map as to where the funds need to be distributed.In operational practices, those three things are the most considered factors in optimizing the fund management, and (4) banks have the credibility in the eyes of the public and are regulated by the prevailing regulations. ${ }^{17}$

The utilization of sharia banks as an institution managing the waqf funds is a manifestation of the mandatory function of a bank to manage three sectors of economic customers, namely formal, informal, and voluntary sector.This was inspired by the establishment of SIBL in Bangladesh which operates the bank's function in voluntary sector by raising the funds from the rich customers in the form of Cash Waqf Certificate offerings for social programs. The assignment of sharia banks as the LKS-PWU makes the LKS-PWU banks become very important in the success of money waqf program, whether or not the money waqf fundraising and management heavily depends of the performance shown by LKS-PWU.

By seeing the roles and potentials from the LKS-PWU as described above, there are three main factors that give big contributions for LKS-PWU in succeeding the national money waqf, namely the accountable management factor supported by reliable and professional human resources as well as the strong credibility of LKS-PWU in the eyes of the public in raising the

\footnotetext{
${ }^{17}$ Mulya Siregar, "Peranan Perbankan Syariah dalam Implementasi Waqf Uang”, dalam Awqaf, Volume IV,
} Nomor 04, Januari 2011,49-59. 
money waqf funds because it was based on the legitimate and applicable Law and Government Regulations.

The facts show that LKS-PWU has not performed its functions as expected and has not played a maximum role in raising the money waqf funds in Indonesia, although LKS-PWU has many potentials and privileges that can be optimized. There are indications that LKS-PWU is not optimally handling the money waqf fundraising program professionally as expected. Whereas people's expectation on LKS-PWU was so big considering the population of Indonesia of 237 million with Muslim as a majority of $85 \%$ of total population, so there are more than 201 million people. ${ }^{18}$ If the money waqf programs can be optimally implemented by LKS-PWU, there are potentially big funds that can be utilized for people's empowerment and benefits. Based on the data from the Director of Waqf, the money waqf fundraising collected by the LKS-PWU, the total of money waqf collected as in the final balance of December 31, 2016 is Rp. 2,997,666,946. ${ }^{19} \mathrm{This}$ indicates that LKS-PWU has not been optimal in raising the money waqf.

\section{Table 1. Money Waqf Reception}

LKS PWU 2011 to 2016

\begin{tabular}{|c|c|c|c|}
\hline \multirow{2}{*}{ YEAR } & \multirow{2}{*}{ AMOUNT (Rp) } & \multicolumn{2}{|c|}{ GROWTH } \\
\cline { 3 - 4 } & & $\mathbf{R p}$ & $\mathbf{( \% )}$ \\
\hline 2011 & $796,863,767$ & $-948,853,200$ & -54.35 \\
\hline 2012 & $566,277,039$ & $-230,586,728$ & -28.94 \\
\hline 2013 & $2,606,402,878$ & $2,040,125,839$ & 360.27 \\
\hline 2014 & $2,912,038,711$ & $305,635,833$ & 11.73 \\
\hline 2015 & $2,619,118,581$ & $-292,920,130$ & -10.05 \\
\hline November & $2,804,447,258$ & $185,328,677$ & 7.08 \\
\hline 2016 & & & \\
\hline
\end{tabular}

Source: Indonesia Waqf Board (BWI) 2011-2016

(Processed Data).

From the above analysis, it can be seen that the money waqf reception at BWI through the Sharia Financial Institution-Money Waqf Administrator (LKS-PWU) has been quite big although the number is below the expectation. In 2011, the BWI money waqf reception decreased, it was caused by the donation from Susilo Bambang Yudhoyono on 2010. In 2012, the money waqf reception also decreased, but it was not too significant compared to the previous year. In 2013 , the BWI money waqf reception increased significantly with the growth of $360.27 \%$. BWI in its implementation has been cooperated with LKS-PWU to execute the money waqf fundraising strategies actively by socializing the money waqf across Indonesia and involving all the LKSPWU networks. This practice of utilizing the moment of pilgrimage departure was held in every departure point. Unfortunately, this strategy is not repeated on the following year, the reason was because the lack of financial for the promotion costs. In 2014, the reception increased for $11.73 \%$. On 2015, the BWI money waqf reception decreased, but until November 2016, the BWI money waqf reception increased by $7.08 \%$.

The decreasing amount of money waqf reception in BWI through the LKS-PWU was mainly caused by lack of socialization. The ineffectiveness of money waqf socialization by the

${ }^{18}$ Data BPS 2010

19 Wawancara dengan Sanurdi Abbas di Kantor Kementerian Agama RI pada tanggal 6 Januari 2017 
LKS-PWU makes the money waqf reception in BWI has not been maximized and lack of commitment from the LKS-PWU. ${ }^{20}$ The money waqf fundraising should be increased every year, hence the hard work from all related parties are expected in order for this to succeed.The success of money waqf is expected to bring positive impact for people's welfare because with the big amount of funds collected, there will be more productive business that can be more developed.

4. Supporting Factors and Deterring Factors

a. Supporting Factors

There are several supporting Factors in collecting cash waqf on BWI having a network of branch offices located in all of provinces, regencies, or cities throughout Indonesia. A banking institution is an institution that has experience in managing public funds and is also experienced as an intermediary institution between surplus spending units and deficit spending units. With this experience, if Islamic banking institution is mandated to manage cash waqf, this, for sure, can be done quickly because of such an experience. This is also because of the human resources at LKS$P W U$, who are professional in their fields.

As a manager of funds to be distributed to certain parties, banking institutions have experience, information and distribution maps to which the funds can be distributed. In the next operational practices, these three things are factors that will always be considered in optimizing fund management, and Bank has public credibility and is controlled by the prevailing laws and regulations.

There are 22 banks appointed by the government, as Syariah Financial Institution-Cash Waqf Manager (Lembaga Keuangan Syariah-Pengelola Wakaf Uang (LKS-PWU)), as follows:

\begin{tabular}{|c|l|c|l|}
\hline No. & \multicolumn{1}{|c|}{ Name of Bank } & No. & \multicolumn{1}{|c|}{ Name of Bank } \\
\hline 1 & BNI Syariah & 12 & BPD Jawa Timur \\
\hline 2 & Bank Muamalat & 13 & Bank Sumut \\
\hline 3 & Bank DKI Jakarta & 14 & Bank CIMB Syariah \\
\hline 4 & Bank Syariah Mandiri & 15 & Bank Panin Syariah \\
\hline 5 & Bank Mega Syariah & 16 & BRI Syariah \\
\hline 6 & Bank BTN Syariah & 17 & BPD Sumsel dan Babel Syariah \\
\hline 7 & BPD Syariah Daerah Yogyakarta & 18 & Bank Jabar Banten Syariah \\
\hline 8 & Bank Syariah Bukopin & 19 & BPRS Harta Insan karimah \\
\hline 9 & BPD Jawa Tengah & 20 & Bank Kaltimtara Syariah \\
\hline 10 & BPD Kalimantan Barat & 21 & Bank Kalsel Syariah \\
\hline 11 & BPD Riau & 22 & Bank Danamon Syariah \\
\hline
\end{tabular}

b. Detering Factors

There are several detering Factors in collecting cash waqf on BWI:

1. Many people as well as LKS PWU human resources do not have a good comprehension about cash waqf, laws and regulations regarding waqf, as well as the business process from receiving to managing cash waqf.

\footnotetext{
${ }^{20}$ Hasil wawancara Ahmad Junaidi, Direktur Eksekutif Badan Waqf Indonesia (BWI).
} 
2. The information dissemination of laws and regulations regarding cash waqf and the rights and obligations of LKS PWU has not been maximized.

3. LKS PWU is less active in disseminating information on and collecting cash waqf, and the use of the fund is not known to public.

4. The number of cash waqf data collection has declined.

5. Many LKS PWU do not understand the procedure for depositing cash waqf funds.

6. Not all LKS PWUs have made products and information dissemination tools for cash waqf.

7. Transfer of knowledge in $L K S P W U$, when there is a rotation of employees, has not run optimally.

8. There are no joint cash waqf programs or events to disseminate information on cash waqf.

9. There is no intermediary LKS model between cash waqf Nazhir and land waqf Nazhir.

10. There is an administrative fee on cash waqf account at LKS-PWU so that the value of the cash waqf asset is reduced.

11. The issuance of cash waqf certificate and cash waqf declaration act has not been running well.

12. There is no accounting standard for recording cash waqf.

13. Ministry of Religious Affairs and BWI have not fully received monthly cash waqf reports from $L K S-P W U$.

14. BI and OJK's support for cash waqf has not been maximal.

\section{Conclusion}

Cash waqf fundraising has a very big economic potential if it is managed properly with a good synergy. It is because of the following reasons:

1. The potential for cash waqf at BWI is enormous. This is supported by the existence of 22 LKS PWUs that have been appointed by the Minister of Religious Affairs to receive cash waqf throughout Indonesia.

2. The growth of cash waqf at BWI has fluctuated. This can be seen from the growth of cash waqf fundraising at BWI, in 2011 and 2012 it decreased, however in 2013 the receipt of cash waqf increased by $360.27 \%$. This happened because BWI implemented a more active fundraising strategy, namely by conducting information dissemination throughout the country and took the advantage of the moment of Hajj departure. Prospective hajj pilgrims at each embarkation point were provided with information dissemination regarding cash waqf along with the objectives of the waqf projects to be worked on and such a strategy seemed to be effective. The year 2014 also experienced an increase even though it was not as big as the previous year, namely $11.73 \%$. The year 2015 experienced a decline again, but until November 2016, cash waqf receipts at BWI increased again by $7.08 \%$. However, if it is analyzed, it can be seen that the accumulation of cash waqf funds has continued to develop and grow from year to year.

3. There are both supporting and deterring factors that influence the fluctuating growth of cash waqf in Indonesia. The growth of money waqf managed by Indonesia Waqf Agency (Badan Wakaf Indonesia/BWI) shows an uptrend even though it is not significant. The 
practice of money waqf carried out by BWI has been running well enough, but it is not optimal yet. It happens because some Shariah Financial Agencies that receive money waqf (Lembaga Keuangan Syariah Penerima Wakaf Uang/LKS PWU) have not been active. None of them has received money waqf. LKS PWUs feel that they lack information dissemination

\section{Recommendation}

1. The government is advised to be more active in disseminating information on cash waqf or forming waqf ambassadors and making a review of the existing regulations of cash waqf institutions in Indonesia. Cash waqf institutions in Indonesia have their own characteristics that require special attention. This type of institution is relatively new, so it requires supportive and flexible regulations to develop, but it needs regular supervision and adequate funding.

2. Nadzir is expected to be more innovative and active in designing cash waqf fundraising strategies. It is advisable that Nadzir may conduct comparative studies in other countries which have a better development in this area.

3. It is hoped that the government may facilitate regulations which can accommodate cash waqf fundraising problems. In addition, dissemination program on cash waqf requires a good attention because there are still many people who are not yet aware of its implementation.

\section{References}

[1] al-Zuhayli, Wahbah. al-Fiqh al-Islam wa Adillatuh. Kairo: Dar al-Fikr, 2010.

[2] Antonio, Muhammad Syafi'i. Bank Syariah Suatu Pengenalan Umum. Jakarta: kerjasama Bank Indonesia dan Tazkia Institute, 1999.

[3] Arief Budiman, Achmad. “ akuntabilitas lembaga pengelola wakaf” Jurnal Walisongo, Vol. 11 No. 1 (2011), IAIN Walisongo Semarang.

[4] Bakar, Abu, dkk. Filantropi Islam dan Keadilan Sosial: Studi tentang Potensi, Tradisi, dan Pemanfaatan Filantropi Islam di Indonesia. Jakarta: CSRC UIN Jakarta, 2006.

[5] Cajee, A. Z., "Revitalising the Institution of Awqaf in Developing Community." Singapore International Waqf Conference (2007).

[6] Cizacka, Murat, "A waqf in History and Its Implications for Modern Islamic Economies", Journal of Islamic Economic Studies, Vol. 6, No.1. (1998).

[7] Departemen Agama RI. Pedoman Pengelolaan Wakaf Tunai. Direktorat Pemberdayaan Wakaf, 2006.

[8] Direktorat Jenderal Bimbingan Masyarakat Islam dan Penyelenggaraan Haji. Strategi Pengembangan Wakaf Tunai di Indonesia. Jakarta: Direktorat Pengembangan Zakat dan Wakaf, 2005.

[9] Direktorat Pemberdayaan Wakaf. Himpunan Peraturan Perundang-Undangan tentang Wakaf (BadanWakaf Indonesia tahun 2015). Dirjen Bimbingan Masyarakat Islam Kementerian Agama RI.

[10] Djaslim Saladin. Manajemen Strategi. Bandung: Linda Karya, 2000. 
[11] Djunaidi, Achmad. Pedoman Pengelolaan Wakaf Tunai. Jakarta: Direktorat Pengembangan Zakat dan Wakaf Dirjen Biman Islam, 2005.

[12] Jr. F.E. Webster, “ The Changing Role of Marketing in The Corporation”, Vol.4, hlm 1-17, Journal of Marketing, 56 (2012).

[13] Edward R. Freeman. Management Strategic. USA: Pitman Publishing Inc, 1994.

[14] E Nasution, Mustafa, "Wakaf Tunai dan SektorVolunteer", dalam Wakaf Tunai Inovasi Finansial Islam, Peluang dan Tantangan dalam mewujudkan Kesejahteraan Umat (Jakarta: Program Studi Timur Tengah dan Islam/ PSTII-UI, 2006)

[15] Gregory G. Dess; Alex Miller, Management stategic,International edition, 2003.

[16] Hakim, Abdul "Manajemen Harta Wakaf produktif dan Investasi dalam Sistem Ekonomi Syariah" Riptek, Vol.4, No.I1, (2010).

[17] Hanwar, Ahmad Sidiq, "Pengaruh Pengetahuan Zakat, Tingkat Pendapatan, Religiusitas dan Kepercayaan kepada Organisasi Pengelola Zakat terhadap Minat Membayar Zakat pada Lembaga Amil Zakat : (Studi Kasus Terhadap Muzakki di Fakultas Agama Islam dan Fakultas Ekonomi dan Bisnis

[18] Hasanah, Uswatun, "Wakaf Tunai ditinjau dari Hukum Islam", Jakarta: Program Studi Timur Tengah dan Islam/ PSTII-UI, 2006.

[19] Hasanah, Uswatun "Peran wakaf dalam mewujudkan kesejahteraan sosial (studi kasus pengelolaan wakaf di Jakarta Selatan," Disertasi. Jakarta: UIN Syarif Hidayatullah, 1997.

[20] Hendra, "Potensi Wakaf Uang dalam Sistem Ekonomi Islam" tesis pps UIN Syarif Hidayatullah Jakarta, 2002.

[21] --------, "Herry Sutanto dan Khaerul Umam, Manajemen Pemasaran Bank Syariah. Bandung: Pustaka Setia, 2013.

[22] Kim Klein, Fundraising for Social Change, Fourth Edition, (Oakland California: Chardon Press, 2001). 13

[23] Machasin, "Harta Terpendam bernama Wakaf", BuletinWakaf Kementerian Agama RI, Edisi I (2015)

[24] Himpunan Peraturan Badan Wakaf Indonesia (Badan Wakaf Indonesia, 2011)

[25] Djunaidi, Achmad dan Thobieb Al-Asyhar. Menuju Era Wakaf Poduktif. Depok: Mumtaz Publishing, 2008.

[26] H. Bund and J.W. Carrol, “ The Changing Role of The Marketing Function”, Vol 2 , hlm 270-286 Journal of Marketing, 21, N(2005).

[27] Junaidi, Achmad \& Thobib al-Asyhar. Menuju era Wakaf Produktif sebuah upaya progresif untuk kesejahteraan umat. Jakarta: Mitra Abadi Press, 2005.

[28] Lahsasna,A.,"The Role of Cash Waqf in Financing Micro and Medium Size Eterprises (MMES)", Seventh InternationalConference-The Tawhidi Epistemology : Zakat and WaqfEconomy, Bangi, (2010)

[29] M. Quraish Shihab, Tafsir al-Misbah; Pesan, Kesan, dan Keserasian al-Qur'an Volume 2, Jakarta: Lentera Hati, cet.ke IV, 2002.

[30] Muhammad Syafi'i Antonio, "Bank Syari'ah sebagai Pengelola Dana Wakaf” Makalah Workshop Internasional Wisma Haji Batam, 2002.

[31] Mulya Siregar, "Peranan Perbankan Syariah dalam Implementasi Waqf Uang", Vol.4, hlm 49-59 dalam Awqaf, Nomor 04, (2011)

[32] Nana Herdiana Abdurrahman, ManajemenStrategiPemasaranBandung: PustakaSetia, 2015.

[33] Republika, manajemen fundraising dalam penghimpunan harta wakaf, 16 Desember 2008.

[34] Richard Holloway. Menuju Kemandirian Keuangan. Jakarta: YayasanObor, 2001.

[35] Robinson Jr; B. Richard. Strategic Management, Formulation Implementation and

[36] (TWI)," Jurnal Kordinat: Jurnal Komunikasi Antar Perguruan Tinggi Agama Islam Swasta, Vol. VIII No. 1, April 2007.

[37] Supriyono. Manajemen Strategi dan Kebijakan Perusahaan. Jakarta: BPFE, 2006.

[38] Suparman, "Startegi Fundraisng Waqf Uang. Vol. 2 hlm.11 dalam Jurnal Waqf dan Ekonomi Islam, (2009) 
[39] Taqyuddin an-Nabhani, Membangun Sistem Ekonomi Alternatif; Perspektif Islam. Surabaya; Risalah Gusti, 1996.

[40] Thomas Whellen; David Hunger, Strategic Management Bussiness Policy (Addison Wesley Publishing Company Inc, 2006).

[41]Wahbahaz-Zuhaili. al-Fiqh al-IslamiwaAdillatuhu. Damsyik: Dar al-Fikr, Juz VII 